ricades in Parisian history, Hazan's choice to focus on the city is understandable, if not fully justified.

For Hazan, the last victorious barricades were in February 1848, with their role in insurrection declining from that point on. The book ends on an optimistic note, however. While the classical barricade's military role in insurrection may no longer be adequate to match state forces in contemporary cities, their symbolic role can be resurrected to significant effect, as in May 1968, when students used barricades to transform their student revolt into a revolutionary event by reaching back to the illustrious history of the barricade. Moreover, Hazan affirms that the principle function of the barricade, that of obstruction, is as relevant today as it was in previous periods, and new forms of barricades can be conceived to strategically block transportation, information, or energy flows. The final sentence of the book provides us with a synthesis of Hazan's anachronistic militancy, which locates the kernel of past revolutionary potential and brings it into today's conjuncture: "Future insurrections will rediscover, without knowing it, without saying it, and without paving-stones, the way of acting by stifling the power of the state that made the good old barricade so effective" (126). A History of the Barricade is essential reading for anyone seeking a guided tour of the barricades of revolutionary Paris. While it is certainly not the most in-depth account available of the many uprisings that it discusses, Hazan's book is arguably the most readable, and constitutes a marvelous introduction to the history of revolt.

Daniel Benson

New York University

\title{
Margaret E. Boyle. Unruly Women: Performance, Penitence, and Punishment in Early Modern Spain (Toronto: University of Toronto Press, 2015). 184pp. Paperback \$26.95.
}

One of the latest in a series of excellent University of Toronto Press books on the social and cultural context of early modern Spanish literature, Margaret E. Boyle's Unruly Women examines women's performance of penitence and rehabilitation both on the stages and in the correctional institutions of Madrid. In the late sixteenth and early seventeenth centuries, amid the Counter-Reformation, social change, and growing economic difficulty, Spaniards grew increasingly concerned about defending morality and preserving the social order. This concern particularly targeted women. As a result of economic crisis, growing numbers of women fell into poverty, were abandoned by husbands or fathers, became prostitutes or thieves, and otherwise engaged in acts that violated gender expectations as well as legal principles. Spaniards viewed these issues as moral concerns, and addressed them as such, through visible acts of punishment and penitence. Emphasizing these performative elements, Boyle shows that women's deviance was displayed and corrected on the 
stages in public theaters very much as it was in the charitable institutions that sought those women's rehabilitation.

Boyle grounds her argument in the examples of two reformative institutions and three early seventeenth-century plays. The former, the Casa de Santa Maria Magdalena de la Penitencia and a women's jail known as the galera, took in women who were considered to be "public sinners" and sought to reform them. Boyle emphasizes the performative aspects of this rehabilitative process, as women were taken into these institutions via public processions followed by a ritual of symbolic transformation that imitated the vesting of nuns. Even while they were held in strict isolation from the rest of society, they were disciplined through public sermons, corporal punishment, and even branding. Such institutions were not unique but reflected a broader early modern interest in reformative confinement, as evidenced by the rise of beaterios, orphanages, hospitals, and jails.

The plays, in turn, feature women who challenge social and gender norms in varying degrees, from the independent widow (Calderón's La dama duende) to the vixen (Zayas's La traición en la amistad) to the murderess (Vélez de Guevara's La serrana de la Vera). These female protagonists pursue their own interests, including the ability to move freely about the city, to actively court a series of lovers, and to restore their tainted honour through murderous vengeance. This independence and agency challenges gender norms, and so each play must enact some kind of rehabilitation or punishment. The widow finds a new spouse, so that she is under the proper supervision of a man; the vixen is outcast from her social circle; and the murderess is publicly executed.

One of the interesting parallels between institutions and plays in this study is the extent to which Spanish society relied upon deviance and enjoyed it as a spectacle, even as it sought to limit and correct such misbehaviour. Drama in the public theaters was enormously popular even while it was criticized for promoting immorality; critics were concerned about actors (and particularly women) portraying sinful behaviour on stage. Yet the charitable institutions of Madrid directly depended on the funds raised by theatrical performances, so that they could only operate by encouraging the very behaviour they tried to control. Similarly, with the plays, their entertainment value depends on some degree of conflict. The audience can only enjoy the resolution if there was some disruption of order in the first place. Boyle shows that all three of the plays featuring unruly women are at least to some degree sympathetic to their protagonists. Even Gila, the heroine of La serrana de la Vera who avenges her honor in an astonishing wave of murderous violence, is also celebrated as powerful, brave, and a source of pride to her father and her village. Because of this, critics have differed in their interpretation of these plays. Were they meant to display the hypocrisy of gender norms, or to reassure their audience that such norms would always be restored? Boyle's analysis demonstrates that these are not mutually exclusive conclusions. Just as in the case of Mary Magdalene, whose example was widely used after the Council of Trent as a model of confession and 
repentance, $\sin$ is a necessary precursor to redemption. Spanish audiences, whether they were viewing fictional young widows sneaking out of their houses to enjoy the streets of Madrid or public processions of sinful women on their way to rehabilitation, presumably enjoyed the possibility of transgressive behaviour with the knowledge that it would eventually be contained-but not eliminated.

Another contribution of this book is its recognition of the active role of women in both institutions and plays. Rather than viewing women as passive victims of patriarchal control, Boyle shows how women, from the founder of the Madrid galera and her network of elite female supporters to the women in La traición en la amistad who banish the protagonist from their social group, participated in defending social norms. Boyle's work is well grounded in the body of recent scholarship that emphasizes women's active and formative roles in early modern Spanish society. She draws on feminist theory as well as research on drama and the early modern stage, gender, deviance, and custodial institutions. Her argument gives an obligatory nod to Foucault in the introduction, though its relationship to Foucauldian ideas of discipline, and especially their chronology, could have been more productively pursued. Her examples are significantly limited, as the argument rests on an analysis of two Madrid institutions and three plays, one of which may never have been performed in public. Such a short volume could have been strengthened by adding analysis of any number of other institutions and dramatic works. It is nonetheless provocative and effective in demonstrating that institutions and plays adopted similar approaches in addressing the problem of unruly women.

Jodi Campbell

Texas Christian University 